\title{
Landslide inventory mapping and assessment along the Ramche-Jharlang area in Dhading, Rasuwa and Nuwakot districts, Lesser Himalaya Central Nepal
}

\author{
*Jharendra K.C., Deepak Gautam, Purushottam Neupane, and Kabi Raj Paudyal \\ Central Department of Geology, Tribhuvan University, Kirtipur, Kathmandu, Nepal \\ *Corresponding author:jharendrakc03@gmail.com
}

\begin{abstract}
Landslides that are the major hazards, are concentrated along the river valley, road cut sections, cultivated lands and geologically adverse areas like fault zones, incompetent lithology, steep slopes and overhanging cliffs. Present study represents a small part of the Mahabharat Range within the Lesser Himalaya, where landslide inventory mapping was carried out in the Ramche-Jharlang area because it consists of numerous small to large landslides affecting ecology and society. The main objectives were to delineate both present and past landslides with their characters (geometry, geology, hydrogeology, slope geometry, triggering causes of landslides and their impacts) focusing on the present propagating trends in terms of its cause. The field investigation was carried out by field work in the landslide occurring areas, visual inspection, satellite image analysis, photographical analysis, interaction and interview with the locals and the affected groups. The study reveals nail scratching outlook in most of the hills. The slope failures were debris flow, debris slide, mud flow and deep-seated creeps. The Ramche landslide in the eastern part to the Jharlan-Chhyamthali in the western part, have been devastating and active now and then causing huge casualties. The utmost reasons for occurring small to large scale landslides are inherently weak geological setting along with some adverse geological structures in addition to the triggering factors like concentrated precipitation and earthquakes. Systematic landslide hazard mapping and mitigation measures based on the cause and consequences during the planning and construction stages of infrastructures are fundamental steps to reduce loss from landslide disaster in the region.
\end{abstract}

Keywords: Landslides, Lesser Himalaya, Landslide inventory mapping, Debris flows, Debris slides

Paper Received: 31 Jan 2018

Paper Accepted: 8 March 2018

\section{INTRODUCTION}

A landslide inventory is a detailed register of the distribution and characteristics of past landslides. Landslide is an important natural phenomenon. The mountainous region in the Nepal Himalaya is characterized by steep slopes, high relief, densely jointed, fractured and highly weathered rocks. In additional to this, most of the landslides are characterized along the river valleys, road cut sections, cultivated land geologically unstable areas like fault zones, incompetent lithology and overhang cliffs. Among various causes, landslides triggered by heavy rainfall are the most common throughout the area. The study area lies in different parts of Rasuwa, Nuwakot and Dhading districts. The area consists of numerous small to large scale landslides. The study area covered $300 \mathrm{sq}$. $\mathrm{km}$ of toposheet no. 288513 . The area is located between latitude $28^{\circ} 00^{\prime} 00^{\prime \prime}$ to $28^{\circ} 07^{\prime} 00^{\prime \prime}$ and longitude $85^{\circ} 00^{\prime} 00^{\prime \prime}$ to $85^{\circ} 15^{\prime} 00^{\prime \prime}$ (Fig. 1). The study area is accessible by road from Kathmandu about 200 km. The Trishuli Ganga Nadi, Kintan Khola, Mailun Khola, Akhu Khola and the Lapha Khola are the major drainage of the study area. The drainage pattern of the study area is dendritic. Geological and geotechnical studies over landslides have been carried out by a number of researchers in the Rasuwa District, Nuwakot District and the Dhading District. Among them,
Ghimire, Paudel and Pant (2007) studied about the Ramche Landslide. Likewise, Pant (2010) did geological mapping and structural analysis along the Trishuli Valley from Betrawati to Rasuwagadi, Central Nepal. Thapa et al. (2007) did the geological information system (GIS) based quantitative landslide hazard prediction modeling in natural hill slope in the study area. Dahal et al. (2006) comprehensively deals with the road side slope failure during torrential rainfall events in major roads of Nepal including the study area.

Landslides always remain as a catastrophic event that destroys life, property and beauty of nature. It is important for the recognition, classification of such landslides and their effects should be studied and judged before their occurrence. In this regard, the objectives of the present study were (a) to map all the landslides including the major landslides distributed in the field in 1: 25,000 scale toposheet, (b) to assess preliminarily the causes and consequences of landslides to provide geoscientific information of the area on natural hazards

\section{METHODOLOGY}

Aerial photographs and topo maps acquired from the Survey Department and Google maps were interpreted to study 


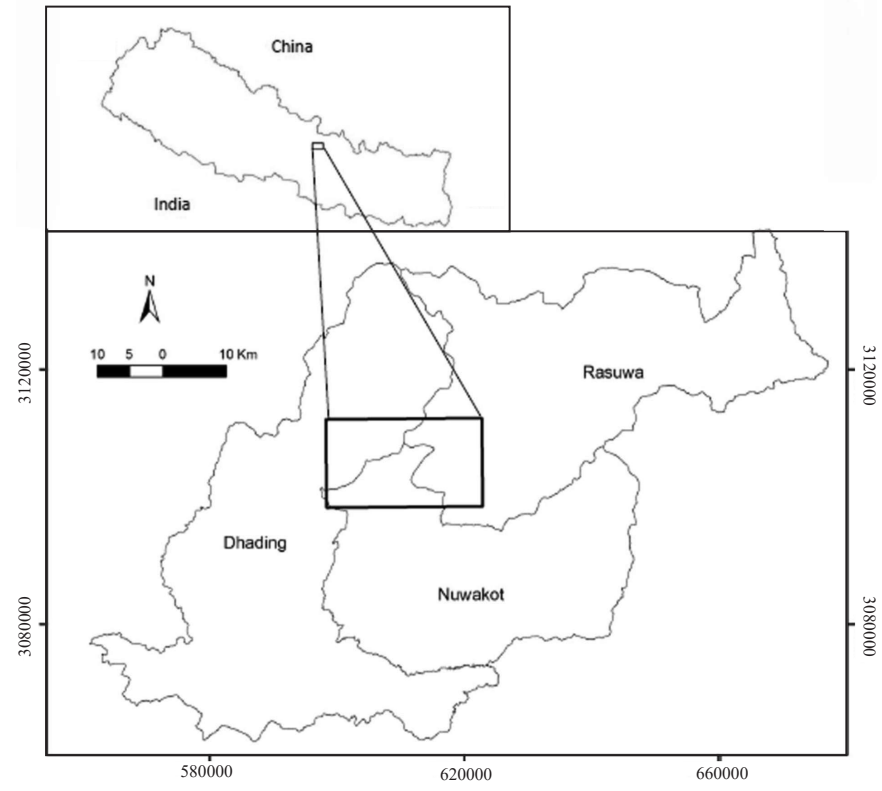

Fig. 1: Location map of the study area

the landslides, erosion features, tectonic structures, existing landuse pattern and lithological units. The topographical maps at 1:25,000 scales were as a base map for the field data collection together with aerial photographs. Geological maps and reports were also reviewed.

For the field investigation, traverses were made along the major road sections, trails, river (Fig. 2a) valleys and along the ridges for the verification of erosion and mass movement. Field survey was focused on collecting data for landslide inventory and their distribution using inventory forms and mapping of various factors that are mostly responsible for triggering landslides. Some of the major landslides were studied in detail using preliminary landslide inventory form for regional inventory. Various data were collected in the field regarding slope geometry, geology, hydrogeology etc.

\section{GEOLOGY OF STUDY AREA}

The study area lies in the Kunchha Formation which is the oldest unit in the Lesser Himalaya as accordance to Stöcklin and Bhattarai (1977). It consists of metasandstone, pellitic to psammitic phyllite, metaconglomerate, gritty phyllite and lesser proportion of quartzite. The Ulleri Gneiss also occupies as the major lithological unit in the study area. Phyllite when gets in contact with water then it swells up leading to the landslide. River terraces developed in this area are often covered by colluvium deposits derived from the high hills lying either side of the river valley.

\section{BRIEF DESCRIPTION OF MAJOR LANDSLIDES IN THE STUDY AREA}

In the study area, the major types of landslides such as debris flow, debris slide and mud flow which were categorized as classified and developed by Varnes (1978). Debris flow is continuous and viscous movement. In the study area, more than $80 \%$ observed landslides were debris flow. High density of soil proportion, high precipitation and high relief are the major causes for such landslides (Fig. 2b). Debris slide is another major type of landslide taking place through the fractures and cracks and dragging the whole soil mass down the slope instead of slurry flow during the heavy precipitation.

\section{Ramche landslide}

The Ramche landslide is one of the famous landslide in the region (Figs. 2c and 2d). It is a debris flow type of landslide. It is active landslide and occurs throughout the year. It becomes more vulnerable during rainy season when there is high precipitation. The extension of the landslide is more than $3 \mathrm{~km}$ and destructs the road section regularly. Haphazard road cut, unscientific way of cultivation and settlement increases the dimension of the landslide. Lack of geotechnical methods increases the degree of vulnerability in the area. The settlement near the Ramche landslide is in great danger.

\section{Gumbadanda landslide}

The Gumbadanda landslide lies in the Gumbadanda area. It is also debris flow type of landslide and extended more than $2 \mathrm{~km}$. It becomes active in the rainy season and damages the settlement, vegetation and road section. About 50 household were completely destroyed by this landslide in the past occurrences of this landslide. Settlement near this landslide bears great threat by this landslide (Figs.2e and 2f).

\section{Jharlan pairo}

The Jharlan pairo (Fig. 2g) is one of the active and greatly extended landslide lies in the upper portion of the Dhading District in Nepal. Its extension is more than 4 sq. $\mathrm{km}$. It is regularly propagating in east-west direction. Villages like Chhyamthali, Kalmarn and Jharlan gaon are being affected by the landslide. The Jharlan Pairo is associated with the shear zone. The contact of this shear zone demarcated the Ulleri Gneiss overlies the host rocks of phyllite and metasandstone. The Jharlaon pairo is the active landslide and regularly threatens the lives in this area.

\section{Darkha debris slide}

The major debris slide was observed along the KuriGorkan road section in the Darkha area. This kind of landslide has been generated due to the seepage of water during the rainy season through the cracks generated in the soil mass. Due to this, block of soil mass detach from the main body dragging down causing the slope failure. In the study area, more than $300 \mathrm{~mm}$ cracks were formed in the soil mass. Based on the field study, the causes of the debris slide can be summarized as the intensive pore water pressure and the landslide above the road section. 

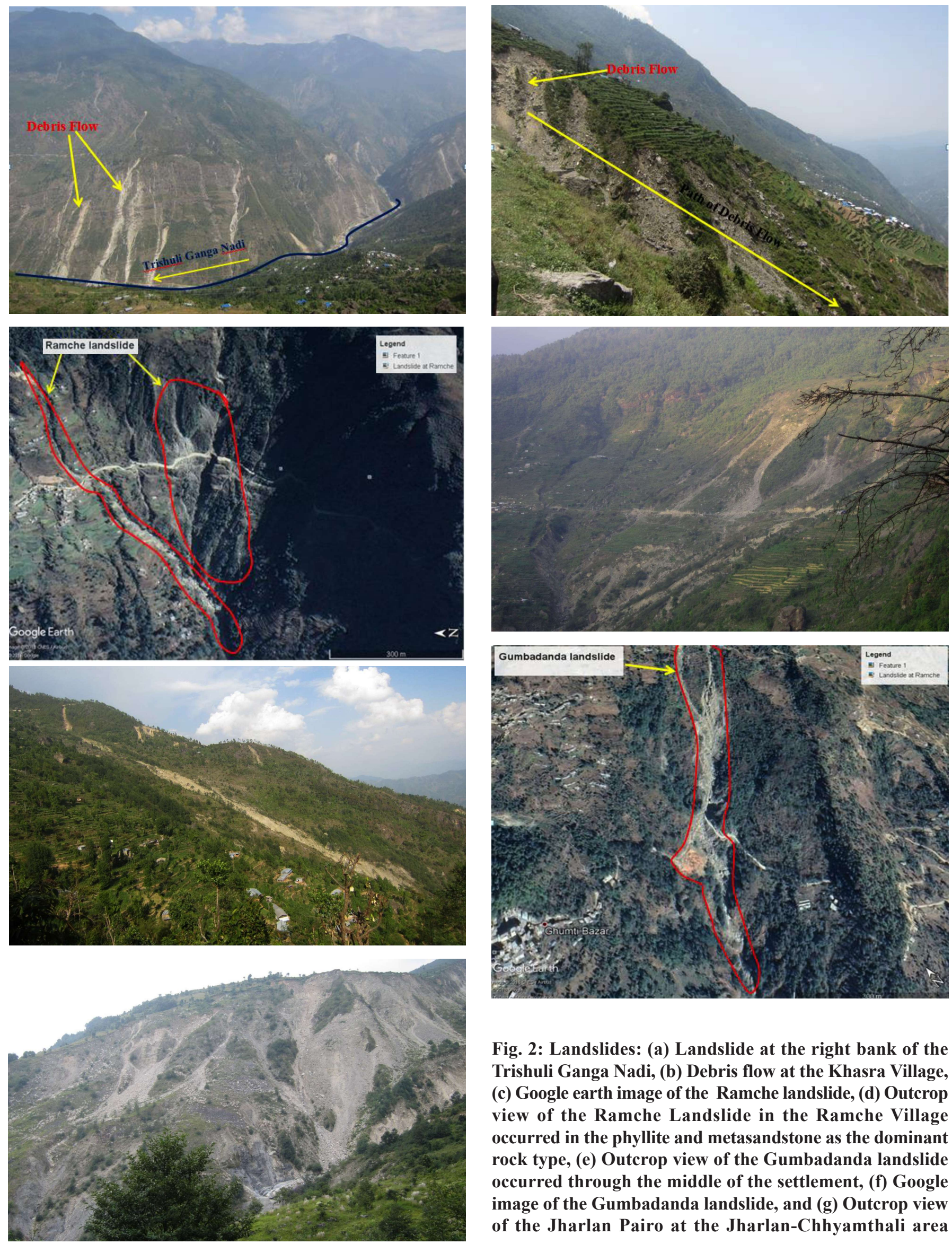

Fig. 2: Landslides: (a) Landslide at the right bank of the Trishuli Ganga Nadi, (b) Debris flow at the Khasra Village, (c) Google earth image of the Ramche landslide, (d) Outcrop view of the Ramche Landslide in the Ramche Village occurred in the phyllite and metasandstone as the dominant rock type, (e) Outcrop view of the Gumbadanda landslide occurred through the middle of the settlement, (f) Google image of the Gumbadanda landslide, and (g) Outcrop view of the Jharlan Pairo at the Jharlan-Chhyamthali area 
Table 1: Core information for the major landslides in the study area

\begin{tabular}{|c|c|c|c|c|c|c|}
\hline $\begin{array}{l}\text { Name of } \\
\text { landslides }\end{array}$ & $\begin{array}{l}\text { Type of } \\
\text { movement }\end{array}$ & $\begin{array}{l}\text { Location } \\
\text { (Districts) }\end{array}$ & Rock type & Land cover/use & $\begin{array}{l}\text { Triggering } \\
\text { causes }\end{array}$ & Impact \\
\hline $\begin{array}{l}\text { Ramche } \\
\text { Landslide }\end{array}$ & $\begin{array}{l}\text { Debris } \\
\text { flow }\end{array}$ & $\begin{array}{l}\text { Ramche, } \\
\text { Rasuwa }\end{array}$ & $\begin{array}{l}\text { Metasandstone, } \\
\text { Phyllite }\end{array}$ & $\begin{array}{l}\text { Settlement, } \\
\text { Cultivated crops }\end{array}$ & $\begin{array}{l}\text { High } \\
\text { precipitation }\end{array}$ & $\begin{array}{l}\text { Destruction of road, } \\
\text { vegetation and } \\
\text { settlement }\end{array}$ \\
\hline $\begin{array}{l}\text { Gumbadanda } \\
\text { Landslide }\end{array}$ & $\begin{array}{l}\text { Debris } \\
\text { flow }\end{array}$ & $\begin{array}{l}\text { Gumbadanda, } \\
\text { Rasuwa }\end{array}$ & $\begin{array}{l}\text { metasandstone, } \\
\text { phyllite }\end{array}$ & Vegetation & $\begin{array}{l}\text { High } \\
\text { precipitation and } \\
\text { haphazard } \\
\text { settlement }\end{array}$ & $\begin{array}{l}\text { Destruction of road, } \\
\text { vegetation, settlement } \\
\text { and changes the } \\
\text { landscape }\end{array}$ \\
\hline Jharlan-Pairo & $\begin{array}{l}\text { Debris } \\
\text { flow and } \\
\text { Debris } \\
\text { slide }\end{array}$ & $\begin{array}{l}\text { Jharlan, } \\
\text { Dhading }\end{array}$ & $\begin{array}{l}\text { UlleriGneiss, } \\
\text { metasandstone } \\
\text { and phyllite }\end{array}$ & $\begin{array}{l}\text { Bare rocks, } \\
\text { cobbles, pebbles } \\
\text { and sand }\end{array}$ & $\begin{array}{l}\text { High } \\
\text { precipitation and } \\
\text { high degree of } \\
\text { loose sediments }\end{array}$ & $\begin{array}{l}\text { Declination of } \\
\text { cultivated lands, } \\
\text { destruction of foot trails } \\
\text { and vegetation }\end{array}$ \\
\hline $\begin{array}{l}\text { Darkha } \\
\text { Landslide }\end{array}$ & $\begin{array}{l}\text { Debris } \\
\text { slide }\end{array}$ & $\begin{array}{l}\text { Darkha, } \\
\text { Dhading }\end{array}$ & $\begin{array}{l}\text { Metasandstone, } \\
\text { phyllite }\end{array}$ & Bare soil & $\begin{array}{l}\text { High } \\
\text { precipitation }\end{array}$ & $\begin{array}{l}\text { Destruction of } \\
\text { settlement, road and } \\
\text { aquatic habitat }\end{array}$ \\
\hline $\begin{array}{l}\text { Salme/Bhalch } \\
\text { e landslide }\end{array}$ & $\begin{array}{l}\text { Debris } \\
\text { flow }\end{array}$ & $\begin{array}{l}\text { Salme/Bhalche, } \\
\text { Rasuwa }\end{array}$ & $\begin{array}{l}\text { Metasandstone, } \\
\text { phyllite }\end{array}$ & $\begin{array}{l}\text { Vegetation, } \\
\text { cultivated crops }\end{array}$ & $\begin{array}{l}\text { High } \\
\text { precipitation }\end{array}$ & $\begin{array}{l}\text { Destruction of aquatic } \\
\text { life, and vegetation }\end{array}$ \\
\hline
\end{tabular}

\section{RESULTS}

The study of landslides in the inventory form is the preliminary step for assessment and resilience of landslide related hazard in the study area. Signs of landslide in the study area are: (a) Falling of loose sediments, (b) Mud and sediments flowing rapidly, (c) Tilted trees or utility poles, (d) Slight movement in soil mass, and (e) Cracks generated in soil mass due to debris slide. Small to large scale landslides were observed in the study area. These landslides were highly influenced by the geology, geomorphology, seismic activities and anthropogenic causes. Major landslides in this area lie in the Kunchha Formation and phyllite and metasandstone were the major rock types. The relationships of landslide occurrence and geology is found to be very crucial. In the study area, the dominant rock types are phyllite and metasandstone which is highly succeptible for the landslide. High density of soil proportion, loose sediments and high relief were the major causes for the landslide. Most of the landslides were concentrated in the river valleys, hills, ridge, roads and streams. Several gully erosion and high density of discontinuities in the rocks, increases slope instability. Similarly, small to large scale earthquakes triggered the major landslides.

Similarly, geomorphology, tectonic activities, hydrogeology are some of the important factors for the reoccurrence of the catastrophic landslides in the study area. Debris flows are supposed to occur more frequently in coarse grained soil and steep slopes whereas the debris slide observed to be occurred in sand and mud mixed medium soil and steep to gentle slopes.
In some extent, human behavior such as random settlement, unplanned way of cultivation, deforestation etc. lead to the slope failure.

Landslides in the study area looked fragile where no any geotechnical methods were applied for controlling the landslides. People were living with the landslides and facing the problems of losing the lives and properties.

Various nail scratching outlook could be evident throughout the study area. To show the landslide distribution pattern and dimension, a geological inventory map (Fig. 3) was prepared. Geological information system (GIS) 10.2 was used for the preparation of the map. Various google maps were observed during the data acquisition period.

The major causes of the landslides identified in the study area are: (a) High relief or steep slopes, (b) High density of annual precipitation, (c) extremely saturated, and loose ground, (d) Long history of slope instability, (e) Unconsolidated sediments, and (f) Haphazard land use and road cut.

\section{CONCLUSIONS}

Landslides were studied in the field through the walkover survey and landslide inventory map has been prepared using the relationship between each landslide and causative factors. Broad distribution of landslides in the study area were reported, tabulated and shown in the map for the preliminary assessment purposes.

GIS, GPS and google earth were effective tool that were 


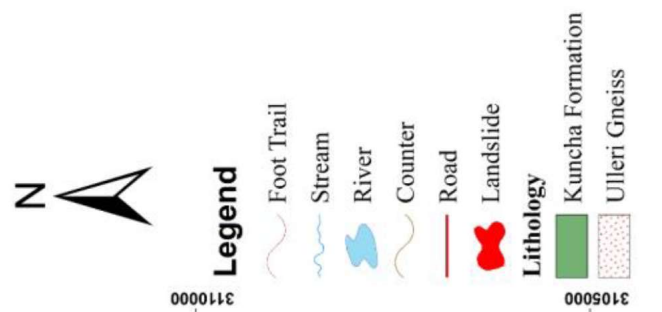

$000001 \varepsilon$

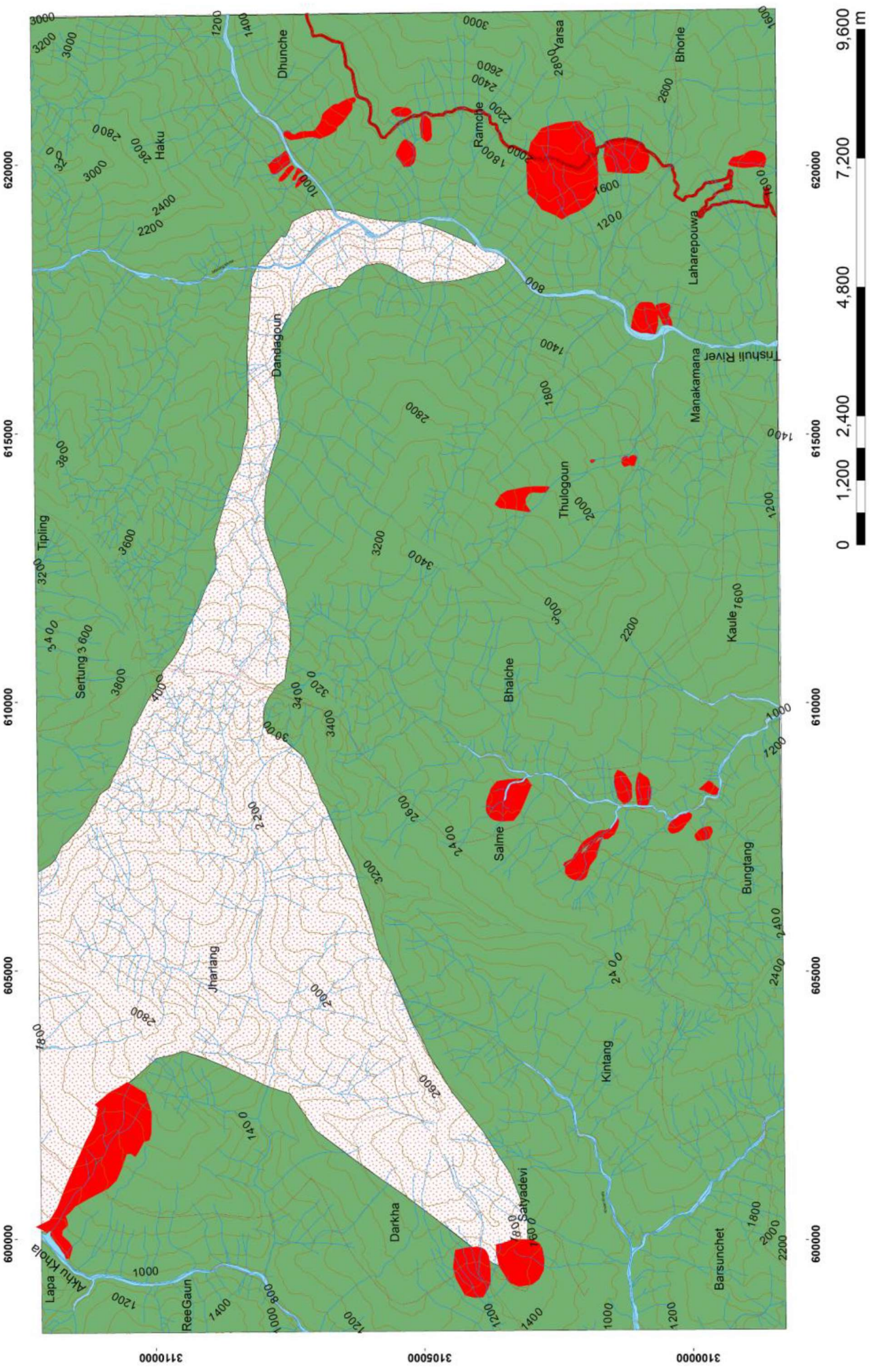

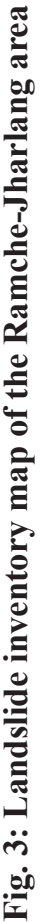


used in landslide inventory mapping to identify in advance potential landslide prone areas.

Most of the landslides were occurring in cultivated lands, along the river valleys, road cut sections, steep slope, overhanging cliffs, fault zones and incompetent lithology.

Pelitic phyllite and highly weathered metasandstone were found to be more vulnerable to landslide than other types of rocks.

\section{ACKNOWLEDGEMENTS}

Authors are grateful to Prof. Dr. Ram Bahadur Sah for his kind support and valuable suggestions throughout the study period. Authors are thankful to Mr. Amit Neupane, Mr. Surendra Shrestha, Mr. Sudarshon Sapkota and Mr. Gunanidhi Pokhrel for valuable help and suggestions in GIS analysis. Authors thank Ashis K.C., Kamal Kafle, Balram Bhandari, Lokmani Oli, Sanjeew Bhujel and Bhupendra K.C. for their assistance during mapping.

\section{REFERENCES}

Dahal, R. K., Hasegawa, S., Masuda, T., and Yamanaka, M., 2006. Roadside slope failures in the Nepal during torrential rainfall and their mitigation. Journal disaster mitigation of debris flow, slope failure and landslides (Interprenet 2007), Universal, v. 2, pp 503-514.
Ghimire, T., Poudel, L., Pant, B., 2007. The devastating ramche landslide (Rasuwa) and the future of Polchet residents. Nepal Geological society (Special Issue), v. 36, p.27.

Pant, B. R., 2010, Lithostratigraphy and Structural Analysis of the lesser and higher Himalaya, between Betrawati and Rasuwagadi, central Nepal, unpublished M. Sc. Thesis, Geology. TU, 54p.

Stöcklin, J. and Bhattarai, K.D., 1977, Geology of the Kathmandu area and central Mahabharat range, Nepal Himalaya. Report of Department of Mines and Geology/ United Nation Development Program (unpublished), 86p.

Thapa, P. B. and Esaki, T. 2007. GIS-based Quantitative landslide hazard prediction modelling in natural hillslope, Agra Khola watershed, central Nepal. Bull. Dept Geol., v. 10, Tribhuvan University, Kathmandu, Nepal, pp. 63-70.

Varnes, D. J., 1978. Slope movement types and processes. In: Schuster, R. L, Krizek, R. J. (eds.) Landslides, analysis and control, special report 176: Transportation research board, National Academy of Sciences, Washington, D. C., pp. 11-33. 